\title{
The Due Diligence Standard and the Prevention of Racism and Discrimination
}

\author{
Paulo de Tarso Lugon Arantes ${ }^{1}$
}

Accepted: 8 December 2021 / Published online: 31 January 2022

(c) T.M.C. Asser Press 2022

\begin{abstract}
The due diligence standard has played a significant role in preventing human rights violations, including racial discrimination. Yet, it is significantly articulated in neutral terms, often failing to grasp the specificities of violations of this type. Moreover, the positive structural impact that due diligence can produce is still subject to debate and is approached with reluctance by human rights courts and monitoring bodies. The principle of substantive (racial) equality has considerably contributed to improving the law on racial discrimination, but with limited impact on collective or structural claims. In the wake of new social events demanding responses to racism beyond the classical individual perspective, it makes it necessary to inquire whether, or to what extent, this standard can play a role in enhancing such structural responses by international human rights law. This article aims to analyze the main components of the due diligence standard (the preventive limb) to assess the relevant shortcomings, and to propose ways forward in order to enhance a structural perspective in racial discrimination.
\end{abstract}

Keywords Due diligence $\cdot$ Vulnerability $\cdot$ Racial discrimination $\cdot$ Positive obligations $\cdot$ Substantive equality $\cdot$ Structural racism

\section{Introduction}

To write an article about the due diligence standard and the prevention of racial discrimination $^{1}$ is to honour the victims of such a scourge worldwide, such as the Dalits in South Asia, the Roma, Sinti, and Travellers in Europe, the blacks in the slums

\footnotetext{
${ }^{1}$ This article applies the phenomena recognized by the Durban Conference (2001) to the term 'racial discrimination', namely 'racism, racial discrimination, xenophobia and related intolerance', in view of several contemporary social and legal events that lead to individual, collective and structural forms of discrimination, marginalization and exclusion. World Conference Against Racism, Racial Discrimination, Xenophobia and Related Intolerance, Programme of Action. UN Doc. A/CONF.189/5 (2001) (DDPA).
}

Paulo de Tarso Lugon Arantes

$1 \quad$ Vitoria, Brazil 
in Brazil, and so many other victims of police brutality, political violence, sexual violence, xenophobia, and exclusion. The author does so with respect and solidarity.

From the seminal standard of due diligence enunciated in Velásquez-Rodríguez $(1988)^{2}$ by the Inter-American Court of Human Rights (IACtHR), a bourgeoning body of international law has applied this standard's elements to racial discrimination, ${ }^{3}$ particularly when it comes to the prevention of racial discrimination. However, it is legitimate to inquire whether an automatic application of the general due diligence standard to the specific perspective of racial discrimination still keeps the promise of rendering human rights treaties effective rather than merely theoretical and illusory. The first main argument of this article is that the due diligence standard is not specifically designed to deal directly with structural discrimination, thus tackling it indirectly, but it can play an important role in dealing with this phenomenon. The second main argument of this article is that, in order to keep such a promise, an application of the due diligence standard should consider the particularities of racial discrimination. More specifically, it is necessary to understand the specific dynamics of racial vulnerability. Rights holders in this scenario are individuals who, by their inherent socio-economic powerlessness, enjoy rights to a lesser extent than others due to their colour, ethnicity, nationality, or origin. The principle of substantive equality, in this regard, has played a significant role during the last decades by opening the legal discussions to social, political, economic, and other circumstances influencing racial inequality. However, its role in addressing instances of systemic discrimination is somewhat limited and has not been sufficiently explored to date. By analyzing the main State obligations relating to the due diligence standard, and addressing its shortcomings and the possible way forward, this article seeks to contribute to a more efficient use of this standard, namely, to have an important role in addressing structural discrimination.

This article is divided into two sections. The first section (Sect. 2) prepares the ground for the discussion and presents a reflection of the reluctance of international human rights law to deal with structural discrimination. The second section (Sect. 3) deals with the due diligence standard applied to racial discrimination, discussing the main State obligations laid down in treaties or implied through case law, followed by a critical analysis of how this standard can enhance a structural approach in racial discrimination. This second section will analyze the most important State obligations in this context, that are part of written law or

\footnotetext{
2 IACtHR, Case of Velásquez Rodríguez v. Honduras. Merits. Judgment of July 29, 1988. Series C No. 4, para. 194.

3 This article uses as a basis the definition of racial discrimination by the ICERD, under its Article 11: '[i]n this Convention, the term 'racial discrimination' shall mean any distinction, exclusion, restriction or preference based on race, colour, descent, or national or ethnic origin which has the purpose or effect of nullifying or impairing the recognition, enjoyment or exercise, on an equal footing, of human rights and fundamental freedoms in the political, economic, social, cultural or any other field of public life.' This concept is comprehensive and has been widely accepted and adopted by many other human rights systems outside the United Nations.
} 
judge-made law. The article ends with concluding comments that bring reflections on the limitations of the due diligence standard to deal with structural racism and the way forward.

The article makes use of several sources from international law: treaties, judgments of international and regional courts, decisions of human rights dispute settlement bodies, writings by legal scholars, and other relevant materials. This article analyses sources from several international human rights regimes and the relevant decisions or judgments emanating from the relevant judicial or quasi-judicial bodies, as a means of finding complementarity among them and contributing to a comprehensive debate on international equality law. The author believes that cross-pollination from different sources and regions is beneficial for the study of international human rights law since it stimulates critical thinking and complementarity among the diverse human rights protection systems. ${ }^{4}$ This article adopts a mixed methodological approach. It mainly takes an analytical perspective, by attempting to evaluate whether (or to what extent) the relevant human rights treaties and relevant interpretations deal sufficiently with structural discrimination. At the same time, it takes a critical perspective, by pointing to instances in which structural discrimination could be enhanced.

\section{Reluctance to Deal with Structural Racial Discrimination and Racial Segregation}

Among a number of definitions of structural discrimination, the most recent one, formulated by the UN High Commissioner for Human Rights, is very authoritative.

[...] the operation of a complex, interrelated system of laws, policies, practices, and attitudes in State institutions, the private sector, and societal structures that, combined, result in direct or indirect, intentional or unintentional, de jure or de facto discrimination, distinction, exclusion, restriction or preference on the basis of race, colour, descent or national or ethnic origin. ${ }^{5}$

\footnotetext{
4 This approach is inspired by the concept of 'human rights integration', Brems (2014), pp. 447-470.

5 United Nations High Commissioner for Human Rights, Promotion and protection of the human rights and fundamental freedoms of Africans and of people of African descent against excessive use of force and other human rights violations by law enforcement officers (Police Brutality and Racism Report), UN Doc. A/HRC/47/53, para. 9. Another definition of this concept: 'refers to rules, norms, routines, patterns of attitudes and behavior in institutions and other societal structures that represent obstacles to groups or individuals in achieving the same rights and opportunities that are available to the majority of the population', Mirjana Najcevska, Structural Discrimination-Definition, Approaches and Trends. Executive Summary of Panelist at the 8th Session of the UN Working Group of Experts on People of African Descent, 18 October 2009. https://www.ohchr.org/EN/Issues/Racism/IntergovWG/Pages/Session8.aspx. Accessed 6 December 2021.
} 
Related to this topic, racial segregation, as a human rights topic, has been articulated since the mid-1990s, ${ }^{6}$ but it has been insufficiently dealt with by international human rights litigation. This issue is commonly (and mistakenly) linked with economic, social, and cultural rights (ESCRs) as if State assistance alone would address the complexities of systemic racial inequality. An idea of rights deficits applied to reinforce, in legal terms, the notion of vulnerability presents a more complex, thus more realistic scenario of similar inequality in civil and political rights (CPRs). Hence, in order to break this systemic vicious circle, marginalized groups, frequently disfranchised from the mainstream political process, need to have upheld their rights of freedom of expression and political participation, as well as, not of the least importance, to have freed themselves from social stigma and prejudices. Such a lack of a combined understanding of rights seems to reflect an obsolete idea that 'social rights' are not justiciable rights, ${ }^{7}$ in their classical sense, to the detriment of more effective solutions to address structural racism. The notion of due diligence has been constantly articulated by the Committee on Economic, Social, and Cultural Rights $(\mathrm{CESCR})^{8}$ throughout its General Comments, which allows a cohesive view of both types of rights.

The theories of indirect ${ }^{9}$ and de facto ${ }^{10}$ racial discrimination have opened important critical thinking to a traditional and formalistic concept of discrimination. They derive from critical legal studies, which pursue substantive equality rather than just formal equality. ${ }^{11}$ In line with these critical studies, the notion of

\footnotetext{
6 Mainly by the CERD, The Prevention, Prohibition and Eradication of Racial Segregation and Apartheid, adopted at its forty-seventh session, UN Doc. A/50/18, 1995, p. 140.

7 Nowadays, the denial of justiciability for ESCRs in international law has lost its importance, in view of the growing body of case law involving these rights and particularly the entry into force of the OPICESCR, yielding a significant international case law. See, mutatis mutandis, Alves (2008), p. 965, commenting on the growing attention by the CERD on economic status as a ground of racial discrimination. The ICERD contains provisions protecting both 'types' of rights.

${ }^{8}$ For instance, the most recent General Comment, following a trend of the last decades: General comment No. 25 (2020) on science and economic, social and cultural rights (Article 15 (1) (b), (2), (3) and (4) of the International Covenant on Economic, Social and Cultural Rights), UN Doc. E/C.12/GC/25, 2020, paras. 43 and 44, among several other excerpts.

9 Under several systems: Council Directive 2000/43/EC of 29 June 2000 implementing the principle of equal treatment between persons irrespective of racial or ethnic origin (Official Journal L 180, 19 July 2000). Art. 2 ICERD and relevant case law e.g., CERD, L. R. et al. v. Slovak Republic, communication No. 31/2003. Opinion of 7 March 2005. UN Doc. CERD/C/66/D/31/200310, para. 10.5; ECtHR, Biao $v$. Denmark [GC], No. 38590/10, ECHR 2016, para. 112; ECRI, General Policy Recommendation $\mathrm{N}^{\circ} 11$ : Combating Racism and Racial Discrimination in Policing. CRI(2007)39, para. 5(b).

${ }^{10}$ Instances of de facto racial discrimination denote situations in which unjustified differentiation is not a result of laws explicitly discriminating certain groups. Rather, these instances result in the fact that such laws do not consider inherent social differences, as explained, e.g., in CERD, General Recommendation No. 32-The Meaning and Scope of Special Measures in the International Convention on the Elimination of All Forms Racial Discrimination, 24 September 2009, UN Doc. CERD/C/GC/32, para. 6.

11 For instance: Fredman and Spencer (2006), pp. 598-606.
} 
vulnerability-based on the specific circumstances of a particular case, ${ }^{12}$ rather than an immutable concept-has given greater support to the promise of human rights law to deliver substantive (racial) equality. A further idea of rights-enjoyment deficits further explores, in a more legal perspective, how both CPR and ESCR, both combined, contribute to a situation of vulnerability. ${ }^{13}$ This idea can be perceived by a number of factors, viz. the propensity of certain racialized groups to suffer violations, the greater severity of the (physical, emotional, economic, social, etc.) impacts of a violation on these groups, a lack of (disaggregated) data, ${ }^{14}$ hampering the design of targeted polices, unequal participation in key decision-making processes, ${ }^{15}$ and the hindered avenues for redress. ${ }^{16}$ In this regard, this article uses the term 'neutral' so as to indicate a failure to take these specificities into account, which may compromise a substantive approach to human rights and real prospects for justice for the discriminated groups. Despite such important developments, indirect and de facto discrimination have been construed within the scope of individual rights, indirectly tackling structural racial discrimination, such as e.g., in the ECtHR's D.H. and Others v. the Czech Republic (2007). ${ }^{17}$ These developments have had the effect of removing real instances of racial discrimination from invisibility, but not dealing essentially with their root causes. However, positive obligations aimed at addressing systemic racism have not been sufficiently derived from case law. At the same time, as will be seen throughout this article, equality and non-discrimination are still formulated to provide individual justice rather than structural transformation.

\section{The Due Diligence Standard and Racial Discrimination}

International human rights law has, without doubt, embraced the due diligence standard $^{18}$ as a set of States' positive obligations in order to prevent human rights violations by putting in place norms, practices, and procedures to, at least, minimize the risk of violations materializing. However, the extent to which such a standard is capable of dealing with structural racism is subject to uncertainty, either because of its inherent limitations or because it is applied under a traditional concept of individual justice. The following sub-sections deal with a brief presentation of the due diligence standard (Sect. 3.1) and its application (and challenges) to racial discrimination (Sect. 3.2).

\footnotetext{
12 Peroni and Timmer (2013), p. 1063: 'vulnerability is relational, particular, and harm-based'.

13 Lugon Arantes (2019), p. 194.

14 Ibid., p. 326.

15 Ibid., p. 324.

16 Ibid., pp. 332-339.

17 The ECtHR's stance on past discriminatory practices is notable, such as in D.H. and Others v. the Czech Republic [GC], No. 57325/00, ECHR 2007-IV, para. 209; Horváth and Kiss v. Hungary, No. $11146 / 11$, para. 116, 29 January 2013.

18 For the purpose of this article, due diligence refers to States' obligations only, different from the corporate practice of the duty of care attributed to non-State actors, which is devoid of a normative value, as delineated by UN Doc. A/73/163.
} 


\subsection{The General Due Diligence Standard}

The due diligence standard in general human rights law has operated as a tool to enhance the effectiveness of State obligations emanating from treaties or judicial interpretation, encompassing a very important ex ante component, by which States must organize their structure through laws, policies, and practices to prevent, as far as possible, human rights violations, so that human rights treaties do not remain merely rhetorical. ${ }^{19}$ Among the many ramifications of such positive obligations, States may be held responsible for violations committed by non-State actors for failing to prevent and redress these violations under specific circumstances, the socalled indirect third-party effect (mittelbare Drittwirkung). ${ }^{20}$ Such understanding is in line with the ample concept of racial discrimination under Article 1.1 of the ICERD. ${ }^{21}$ In the Americas, Simone Diniz v. Brazil (2006), decided the Inter-American Commission on Human Rights ('IACHR'), has also accepted this effect in a case relating to the rejection of a black applicant for a babysitter vacancy, as the relevant advertisement accepted white candidates only. ${ }^{22}$

The scope of the due diligence standard is, to a great extent, a product of judgemade law through evolutive treaty interpretation. This basic standard is coined in the form of positive state obligations in order to guarantee the effectiveness of human rights treaties. A most basic State obligation is to enact legislation to prevent human

19 ECtHR, Airey v. Ireland, 9 October 1979, para. 24, Series A No. 32.
20 Spielmann (1995), p. 72.
21 Above, n. 1.
22 IACHR, Simone André Diniz v. Brazil, Case No. 12.001, Report No. 66/06. OEA/Ser.L/V/II.127 Doc.

22 IACHR, Simone André Diniz v. Brazil, Case No. 12.001, Report No. 66/06. OEA/Ser.
4 rev. 1., para. 43. Examples of treaties that, to different degrees, impose or imply such an obligation: Inter-American Convention against All Forms of Racial Discrimination and Intolerance (A-69), Art. 1.1 (Inter-American Convention on Racism); Convention on the Elimination of All Forms of Discrimination against Women (CEDAW) (Art. 13); the Protocol to the African Charter on Human and Peoples' Rights on the Rights of Women in Africa, Adopted by the 2nd Ordinary Session of the Assembly of the Union, Maputo, CAB/LEG/66.6 (Sep. 13, 2000) (Maputo Protocol) (Art. 8), the Inter-American Convention on the Prevention, Punishment and Eradication of Violence Against Women, 33 I.L.M. 1534 (Belém do Pará Convention) [Art. 7(b)]; the Council of Europe Convention on preventing and combating violence against women and domestic violence, April 7, 2011, CETS No. 210 (Istanbul Convention). This obligation is also found in e.g., the Optional Protocol to the Convention on the Rights of the Child on the sale of children, child prostitution and child pornography, GA Res. 54/263, Annex II, 54 UN (UN OP-CRCSC), Art. 8.1 and the Convention on the Rights of Persons with Disabilities: resolution / adopted by the General Assembly, A/RES/61/106, (CRPD), Art. 13.1 (persons with disabilities). A wealth of case law, general comments and recommendations, and other relevant materials clarify the existence of this obligation, including General Comment No. 8 (2006): The Right of the Child to Protection from Corporal Punishment and Other Cruel or Degrading Forms of Punishment (Arts. 19, 28, paras. 2 and 37, inter alia), 2 March 2007, UN Doc. CRC/C/GC/8, para. 40; The Committee on the Elimination of Discrimination against Women (CEDAWCttee): General Recommendation No. 19-Violence against Women, eleventh session, 1992, UN Doc. A/47/38, para. 9; General Recommendation No. 35 on Gender-based Violence against Women, Updating General Recommendation No. 19, 17 July 2017, UN Doc. CEDAW/C/GC/35, para. 24(b); European Court of Human Rights (ECtHR) Opuz v. Turkey, No. 33401/02, ECHR 2009, paras. 169 and 200; UN Human Rights Committee (HRCttee), General Comment No. 32: Article 14: Right to Equality before Courts and Tribunals and to Fair Trial, 23 August 2007, UN Doc. CCPR/C/ GC/32, para. 9. 
rights violations and, in some instances, to prohibit certain acts and practices. ${ }^{23}$ This standard is also composed of the obligation to monitor and regulate activities that have the potential for violating rights, including private activities. ${ }^{24}$ Public participation in the decision-making processes of legislation and regulation is another component of due diligence. ${ }^{25}$ The obligation to prevent imminent violations directly by the authorities has also been made explicit by case law in this regard. ${ }^{26}$

However, it is legitimate to inquire whether the plain and direct application of this standard to cases of racial discrimination will keep the promise of rendering human rights effective, rather than illusional or theoretical. Moreover, it is also plausible to question to what extent this standard may have a positive impact on addressing instances of structural discrimination. The following subsection will propose some critical arguments through specific State preventive obligations and measures.

\subsection{The Due Diligence Standard Applied to Racial Discrimination-Dialoguing with Structural Discrimination}

Over the last decades, new treaties and evolutive treaty interpretation have built an impressive body of international law aimed at preventing instances of racial discrimination in various forms. Despite the importance of such a body of law in dealing with this scourge, structural discrimination has only been dealt with to a limited extent. Despite such limitations, it is argued that there is a potential for this standard to better articulate and deal with systemic racism. As was seen in Sect. 1, racial equality law is specific and contextual, requiring from state laws, policies and practices also specific consideration for the occurrences of rights deficits vis-à-vis racialized groups. In order to render due diligence as effective as possible and to enhance

\footnotetext{
23 Important case law and documents include ECtHR i.a. Osman v. the United Kingdom, 28 October 1998, para. 115 Reports of Judgments and Decisions 1998-VIII; Kılıç v. Turkey, No. 22492/93, para. 62, ECHR 2000-III; Perevedentsevy v. Russia, No. 39583/05, para. 91, 24 April 2014; HRCttee, General Comment No. 20: Prohibition of Torture and Cruel Treatment or Punishment, adopted on 10/03/92. UN Doc. A/47/40 (1992), Annex VI (pp. 193-195), para. 13.

24 Important case law and documents include ECtHR, Van der Mussele v. Belgium, 23 November 1983, paras. 28-30, Series A No. 70 (regulation of the legal profession); Storck v. Germany, No. 61603/00, para. 103, ECHR 2005-V (health facility); and O'Keeffe v. Ireland [GC], No. 35810/09, para. 150, ECHR 2014 (extracts) (private school); IACtHR's Case of Ximenes Lopes v. Brazil. Merits, Reparations and Costs. Judgment of July 4, 2006. Series C No. 149. CESCR, General Comment No. 24 on State Obligations under the International Covenant on Economic, Social and Cultural Rights in the Context of Business Activities, adopted on 10 August 2017. UN Doc. E/C.12/GC/24, para. 22.

25 The recently adopted Escazú Agreement is a good example of a State obligation to allow public participation. ECLAC, Regional Agreement on Access to Information, Public Participation and Justice in Environmental Matters in Latin America and the Caribbean (4 March 2018), CTC-XXVII-18. On the case law, see ECtHR, Hatton and Others [GC], para. 61; Giacomelli v. Italy, No. 59909/00, para. 82, ECHR 2006-XII; Hardy and Maile v. the United Kingdom, No. 31965/07, para. 219, 14 February 2012; IACtHR, The Environment and Human Rights (State Obligations in Relation to the Environment in the Context of the Protection and guarantee of the Rights to Life and to Personal Integrity-Interpretation and Scope of Articles 4(1) and 5(1) of the American Convention on Human Rights). Advisory Opinion OC-23/17 of 15 November 2017. Series A No. 23, paras. 213-218.

26 E.g., ECtHR, Osman v. the United Kingdom, 28 October 1998, para. 115, Reports of Judgments and Decisions 1998-VIII.
} 
its capacity to deal with structural racial discrimination, such specificity should be considered.

This sub-section is divided into six further sub-sections, namely on the obligation to enact legislation to prevent acts of racial discrimination; the obligation to produce disaggregated racial and ethnic data; the obligation to monitor instances of racial discrimination; the obligation to prevent racial discrimination directly by State agents; preventive measures to protect indigenous lands; and State obligations relating to privatization in the context of racial discrimination. The choice of these obligations is grounded on their relevance to international human rights law, as they form part of treaty provisions or highly authoritative judgements, scholarly writings and social debates. Even when there is no consensus on the obligation to implement a certain measure, as in the case of the elaboration of data disaggregated by racial factors, it is important to discuss its shortcomings, its importance for the subject matter, and the way forward.

\subsubsection{The Enactment of Specific Legislation}

The preventive role of enacting legislation in order to prohibit acts of racial discrimination or to protect the rights of discriminated groups is undeniable. A primary obligation for States ratifying human rights treaties is to adapt their domestic legal system in order to implement the relevant treaty provisions. Hence, anti-discrimination laws, proposed before a democratically elected legislature, debated through transparent means in parliament and society at large, counting on the effective participation of the affected groups, are one of the most effective deterrents of acts of racial discrimination and racism.

A number of treaty provisions, and a considerable body of case law, impose an obligation on the State to enact specific legislation. Some instances of racial discrimination are so serious that they can only be deterred by the enactment of criminal law, as required expressly in some international criminal law and human rights treaties. The most concrete example is the crime of genocide, stipulated in the UN Genocide Convention, under Article $\mathrm{V},{ }^{27}$ as also reaffirmed by the ICJ in the Bosnia v. Serbia case (2007). ${ }^{28}$ This case speaks of a State's obligation to penalize acts committed by private individuals ${ }^{29}$ or individuals acting in any official capacity. ${ }^{30}$ This obligation is also evident in the International Convention on the Elimination of All Forms of Racial

\footnotetext{
27 UN Genocide Convention, Art. III: At least in relation to the acts of genocide; conspiracy to commit genocide; direct and public incitement to commit genocide; attempt to commit genocide; and complicity in genocide.

28 ICJ, Application of the Convention on the Prevention and Punishment of the Crime of Genocide (Bosnia and Herzegovina v. Serbia and Montenegro), Judgment, ICJ Reports 2007, p. 43, para. 144.

29 UN Genocide Convention, Art. IV: 'persons committing genocide or any of the other acts enumerated in article III shall be punished, whether they are constitutionally responsible rulers, public officials or private individuals.'

${ }^{30}$ Gaeta (2007), p. 640, for whom a positive duty of diligence under this Convention is certain, although she criticizes the fact that the ICJ did not sufficiently articulate on a negative obligation for the State itself not to commit genocide.
} 
Discrimination (ICERD) under Article 2.1(d). ${ }^{31}$ Moreover, Article 4 of the ICERD imposes on States parties the duty to criminalize the dissemination of ideas based on racial superiority; violence, hatred or incitement to racial discrimination; the functioning of organizations and activities that promote and incite racial discrimination; and the promotion and incitement of racial discrimination by public authorities. Those acts, together with the prohibition of financing these acts, ${ }^{32}$ represent a minimum content to be considered as a crime in the domestic jurisdictions of the signatory States. ${ }^{33}$ The explicit mentioning of the above obligations implies that the ICERD itself is not self-executing but requires additional legislative efforts from States parties ${ }^{34}$ by means of positive legislative obligations. In fact, the Committee on the Elimination of Racial Discrimination (CERD) has recommended the expeditious adoption or strengthening $^{35}$ of comprehensive legislation prohibiting direct and indirect racial discrimination, ${ }^{36}$ specific laws to combat racial hate speech and hate crimes, ${ }^{37}$ or to incorporate the principle of equality in legislation. ${ }^{38}$ Norms aimed at protecting specific groups have also been recommended. ${ }^{39}$ Sanctions for perpetrators should be proportionate, and States should have in place a panoply of legal and administrative measures ${ }^{40}$ to prevent acts such as racial hate speech, according to the particular circumstances of the case. ${ }^{41}$ The European Commission against Racism and Intolerance (ECRI), for its part, has underscored that a minimum core of acts are to be criminalized, viz. genocide ${ }^{42}$ and hate-related acts, ${ }^{43}$ while other forms, e.g., public incitement to violence, hatred, or discrimination, should be criminalized in their intentional forms only. ${ }^{44}$

\footnotetext{
${ }^{31}$ ICERD, Art. 2.1(d): 'Each State Party shall prohibit and bring to an end, by all appropriate means, including legislation as required by circumstances, racial discrimination by any persons, group or organization.' The CERD affirmed that the expression 'as required by circumstances' implies a discretion concerning the means to implement the obligation, but not an option as to whether or not to criminalize the enumerated violations. See: Mahalic and Mahalic (1987), p. 86; CERD, Report 18th Session, 389th meeting. UN Doc. CERD/C/SR.389, 1978, para. 20.

${ }^{32}$ CERD, Report 18th Session, 389th meeting (1978), para. 5, stressing that the financing of the other activities is to be included in the list of activities to be punished.

${ }^{33}$ Idem, para. 3.

${ }^{34}$ CERD, Study on the Implementation of Article 4 of the International Convention on the Elimination of All Forms of Racial Discrimination, UN Doc. A/CONF/119/10, 1983, para. 216; and CERD, Report 18th Session, 387th Meeting, UN Doc. CERD/C/SR.387, pp. 27-28, para. 3.

${ }^{35}$ CERD, Concluding Observations on Ireland, UN Doc. CERD/C/IRL/CO/5-9, 2020, para. 20.

${ }^{36}$ CERD, Concluding Observations on Cambodia, UN Doc. CERD/C/KHM/CO/14-17, 2020, para. 12.

${ }^{37}$ Idem, para. 14.

${ }^{38}$ CERD, Concluding Observations on Israel, UN Doc. CERD/C/ISR/CO/17-19, 2020, para. 12; Concluding Observations on Uzbekistan, UN Doc. CERD/C/UZB/CO/10-12, 2020, para. 8.

${ }^{39}$ HRCttee, Concluding Observations on Kenya, UN Doc. CCPR/C/KEN/CO/4, 2021, para. 51(a) (adoption of a specific law to protect the rights of indigenous peoples).

${ }^{40}$ CERD, General Recommendation No. 35-Combating Racist Hate Speech, 26 September 2013. UN Doc. CERD/C/GC/35, para. 9.

${ }^{41}$ Meron (1985), p. 297 and Schwelb (1996), pp. 996-997. Also, in CERD, General Recommendation No. 35 , para. 12 .

${ }^{42}$ ECRI, General Policy Recommendation No. 7, para. 19.

${ }^{43}$ Idem, para. 18.

${ }^{44}$ Idem.
} 
Moreover, the racist motivation in a given crime must be considered as an aggravating circumstance. $^{45}$

But critically, a neutral view of the obligation to prevent racial discrimination may fall short of practical effects if it does not consider intrinsic deficits facing marginalized groups. Norms to combat racial discrimination should be elaborated in consultation with the affected groups, ${ }^{46}$ as they hardly have access the mainstream legislative processes. ${ }^{47}$ Without their participation and political pressure, the enactment of specific legislation to protect them may again perpetuate racial biases, ${ }^{48}$ as these groups may not be sufficiently heard with regard to their specific needs and the ways in which to enjoy rights. The motto "nothing about us without us ${ }^{49}$ through legislative processes, empowering and removing racial biases is of the utmost importance. In this regard, the HRCttee has now fully embraced the principle of free prior and informed consent when recommending States parties to review legislation in order to protect indigenous peoples. ${ }^{50}$

Moreover, a law-making process to tackle racial discrimination should focus on dismantling its structure, 'beyond a mere summation of individualized acts', but examining its root causes, driving forces, and practical manifestations. Besides meaningful participation by the affected communities, this process should be guided by objective data, statistics disaggregated into race and ethnicity, transparency, and constant measurement through impact indicators. ${ }^{52}$

The enactment of legislation is the beginning and not the end of States' efforts in preventing racial discrimination. The proper enforcement of legislation requires a series of other measures, such as sensitization campaigns, combating stereotyping and stigmas, the monitoring and empowerment of racialized groups, and overall genuine political will. A paradigm of failed legislative efforts in this regard is the persistence of cases of caste-based discrimination in South Asia. A number of countries affected by this practice have adopted constitutional and legal provisions forbidding caste discrimination and the abolition of 'untouchability practices' ${ }^{53}$ Yet, de

\footnotetext{
45 Idem, para. 21; CERD, General Recommendation No. 34-Racial Discrimination against People of African Descent, 3 October 2011. UN Doc. CERD/C/GC/4, para. 84 and the Outcome document of the Durban Review Conference (Durban Review) (2009), para. 84; Council Framework Decision 2008/913/ JHA of 28 November 2008, Art. 4.

46 CERD, Concluding Observations on Uzbekistan, UN Doc. CERD/C/UZB/CO/10-12, 2020, para. 11.

47 See: e.g., CERD, Concluding Observations on Nepal, UN Doc. CERD/C/NPL/CO/17-23, 2018, para. 22.

48 For instance, in Biao v. Denmark, the ECtHR observed that the debates in the country's Parliament on a bill dealing with family reunion negatively depicted Danish citizens of foreign origin, leading to a racial bias in the law itself. [GC], No. 38590/10, para. 126, 24 May 2016.

49 The term 'nihil de nobis, sine nobis' has been historically used to imply a meaningful participation by the affected population in decisions that affect their lives. It is today commonly applied in the antidisability movements, but also to a large extent in the anti-racist movement. In this regard, see the 'Police Brutality and Racism Report', para. 21, recommending the active and meaningful participation of people of African descent and their organizations in the State institutions.

${ }^{50}$ HRCttee, Concluding Observations on Finland, UN Doc. CCPR/C/FIN/CO/7, 2021, para. 43.

51 Police Brutality and Racism Report, p. 18.

52 Ibid.

53 E.g., CERD, Concluding Observations on India, UN Doc. CERD/C/IND/CO/19 (2007), para. 13.
} 
facto segregation occurs in many events in their daily lives, such as access to water sources, places of worship, housing and educational facilities, as well as frequent violence arising from inter-caste marriages. ${ }^{54}$ This failure demonstrates another shortcoming of only enacting legislation to prohibit racial discrimination if this is not articulated with a wide series of other awareness-raising, training, information and facilitating policies for this marginalized community. The enforcement of legislation requires political will and a strong signal from leading state officials that the laws enacted must be enforced. Yet, enforcement often finds its limits where stereotypes and stigmas are well entrenched, which, in turn, discourages the administration and Parliament, for electoral reasons, from acting against the so-called 'will of the people' or not disturbing 'social harmony'. ${ }^{55}$

\subsubsection{Disaggregated Data-Paving the Way for True Structural Litigation?}

The elaboration of disaggregated (racial) data has an undeniable preventive role, enabling authorities not only to cease a vast number of violations but also to prevent new violations from materializing through targeted indicators and policies. ${ }^{56}$ It allows governments to allocate resources correctly to tackle the specific root causes of racial discrimination, thus correctly guiding policy efforts. Its importance is recognized in the 2030 Agenda, ${ }^{57}$ and the obligation to elaborate disaggregated data is explicit in some treaty texts ${ }^{58}$ and is construed by several UN treaty bodies. ${ }^{59}$ Among these bodies, the CERD emphatically reinforces that compliance with ICERD rights relies considerably on equality data. ${ }^{60}$ Yet, the collection, analysis and application of this data broken down by ethnic origin, race, or nationality remain an

\footnotetext{
${ }_{54}$ E.g., CERD, Concluding Observations on Nepal, UN Doc. CERD/C/NPL/CO/17-23 (2018), para. 13.

55 The UN Special Rapporteur on Minority Issues has explained while studying this issue: 'due to caste prejudice or deference shown to perpetrators from higher castes, law enforcement officers may refuse to register and/or investigate cases brought by individuals from lower castes. In some instances, these officers perceive caste-based discrimination as a social issue to be solved within the community rather than a crime. Refusal to register such cases as criminal offences is justified as preserving "social harmony".' UN Doc. A/HRC/31/56, 2016, para. 61.

56 De Beco (2013), p. 386.

57 United Nations General Assembly (UNGA) Resolution 70/1-Transforming our World: The 2030 Agenda for Sustainable Development, Target 17.18.

58 Inter-American Convention on Racism, Art. 12; CRPD, Arts. 31.1 and 31.2.

59 Recommendations of UN treaty bodies on the elaboration of data disaggregated into racial factors: HRCttee, Consolidated Guidelines for States Reporting, CCPR/C/66/GUI/Rev.2, para. C.6; and CESCR, E/C.12/2008/2, paras. 3 and 10; CEDAWCttee, e.g., CEDAW/C/DEN/CO/7, 2009, on Denmark (minority women), CEDAW/C/RUS/CO/8, 2015, (nationality of women suffering violence). CRC CRC/C/VEN/ $\mathrm{CO} / 2$ (2007), on Venezuela (Afro-descendent population); and CRC/C/AUS/CO/4, 2012, on Australia (indigenous children).

${ }^{60}$ CERD, e.g., Guidelines for Reporting, UN Doc. CERD/C/2007/1; General Recommendation No. 32, stressing the need for accurate data, disaggregated by race, ethnicity and other grounds, with a gender perspective, in order to appraise the specific needs of temporary special measures, para. 17. See also DDPA, paras. 31 and 92 in the Durban Review, para. 103.
} 
exception, rather than the rule, as the UN High Commissioner for Human Rights remarked in her 2021 report on police brutality and racism. ${ }^{61}$

In Europe, such an obligation is unclear. The ECtHR has only indirectly dealt with statistical data and has so far not pronounced any further on a State obligation to elaborate such data. ${ }^{62}$ The Racial Equality Directive simply speaks of a "national knowledge base on discrimination., ${ }^{63}$ whose national surveys rarely produce data broken down into ethnicity or a similar condition. ${ }^{64}$ The entry into force of the General Data Protection Regulation (GDPR), ${ }^{65}$ which focuses on privacy and data protection, amounts to further resistance, although this regulation does not prohibit the elaboration of disaggregated data, but imposes several conditions for processing data on individuals who belong to a certain ethnic group ('special categories'). ${ }^{66}$ By contrast, the European Commission against Intolerance and Racism (ECRI) reinforces the need to process data more consistently, systematically and comprehensively, while also rejecting the argument of a failure to elaborate disaggregated data only on the grounds of data protection. ${ }^{67}$ Scholarly works have pointed out that there are conciliatory views between the production of equality data and the infringement of privacy rights. ${ }^{68}$ ECRI's opinion is more than justified in view of the diversification of the population in the region, which requires a shift from a formalist view to equality (being colour blind) and to a more substantive one that embraces the awareness of Europe's ethnic diversity. ${ }^{69}$

Such deficiency is part of a vicious circle that perpetuates structural racism: disaggregated data is not collected or produced because of a lack of racial awareness by policymakers. At the same time, racially-blind policies do not drive public resources and attention to the root causes of racism, thereby feeding the exclusion of racialized sectors from the mainstream of policing, opportunities, services, and rights.

The hesitance in accepting the elaboration of disaggregated data in the context of racial discrimination is considerably influenced by the individualist notion of human rights, instead of being a plausible contemporary understanding that human

\footnotetext{
61 UN Doc. A/HRC/47/53, para. 16.

62 ECHR, D.H. and Others v. The Czech Republic, para. 186.

63 EU Racial Equality Directive, Art. 13.

64 Open Society Foundation, 'Ethnic Origin and Disability Data Collection in Europe: Measuring Inequality-Combating Discrimination', 19. https://www.opensocietyfoundations.org/sites/default/files/ethnic-origin-and-disability-data- collection-europe-20141126.pdf. Accessed 6 December 2021.

65 Regulation (EU) 2016/679 of the European Parliament and of the Council of 27 April 2016 on the Protection of Natural Persons with Regard to the Processing of Personal Data and on the Free Movement of such Data, and Repealing Directive 95/46/EC.

66 Regulation (EU) 2016/679 of the European Parliament and of the Council of 27 April 2016 on the protection of natural persons with regard to the processing of personal data and on the free movement of such data, and repealing Directive 95/46/EC: (a) the processing of data revealing racial or ethnic origin, political opinions, religious or philosophical beliefs, or trade union membership, and (b) the processing of genetic, biometric or health data 'for the purpose of uniquely identifying' a person's sex life or sexual orientation.

67 ECRI, General Policy Recommendation No. 15, on Combating Hate Speech, Adopted on 8 December 2015, CRI(2016)15, para. 3(d).

68 For instance: De Schutter and Ringelheim (2010); Makkonen (2012).

69 Simon (2012), p. 1367.
} 
rights play an undeniable role in changing racist structures in society. Yet, an example of this hesitancy is the Explanatory Report to Protocol 12 ECHR which clearly rejects any collective or structural claims. ${ }^{70}$ The IACtHR's bold approach to patterns of (racial) discrimination has paved the way for litigation that pays greater attention to structural racism ${ }^{71}$ due to its comprehensive reparations practice, which has not been fully implemented by the respondent States, however. The ECtHR's pilot judgment has the potential for dealing with instances of structural discrimination, particularly after being formally recognized by the Court's rules of procedure, hinting that the Court would be ready to deal with more substantive issues rather than merely avoiding repetitive cases in its docket. ${ }^{72}$ There is momentum for the respective supervision mechanism of the CoE Council of Ministers to use the full potential for structural transformation by recommending not only legislative reforms but also monitoring mechanisms, the elaboration of disaggregated data, the participation of racialized groups, and racial awareness campaigns. Several other international mechanisms available today do not attain clear outcomes. ${ }^{73}$

\subsubsection{The Obligation to Monitor Instances of Racial Discrimination}

Preventative measures in international human rights law have gained particular importance in the form of positive obligations that, under specific circumstances, may be required by States. In this specific context, a set of measures for monitoring and regulation have been identified as being necessary to prevent or avoid the recurrence of racial discrimination by both private and public sectors.

Monitoring is more than a one-shot preventive measure. It consists of a continued act which is well grounded in a policy put in place to verify whether the policy's objective has been achieved along the course of its implementation and to correct possible implementation failures. Specifically, in the context of racialized groups, monitoring has some key interrelated objectives. The first is to ascertain whether a law or policy that, in theory, aims at institutionalizing a given right to the whole of the population in fact extends the relevant benefits to traditionally discriminated groups. The second is to ascertain whether a given law or policy has similar effects

\footnotetext{
70 The report restricts the scope of Protocol 12, which enables an independent non-discrimination clause in the ECHR for the 'guarantee of individual rights which are formulated in terms sufficiently specific to be justiciable.', leaving temporary special measures ('affirmative action') as a policy option for States parties, para. 16.

71 See: Abramovic (2009), p. 19.

72 Rule 61.3 of the ECHR: 'The Court shall in its pilot judgment identify both the nature of the structural or systemic problem or other dysfunction as established as well as the type of remedial measures which the Contracting Party concerned is required to take at the domestic level by virtue of the operative provisions of the judgment.'

73 For instance, CERD's early warning mechanism on the prevention of atrocities (see A/48/18, Annex III) and the HRC's complaint procedure, the former ' 1503 procedure' (HRC 5/1-Institution-building of the United Nations Human Rights Council, paras. 85-88). The CoE's collective procedure under the European Social Charter has a broader structural scope, but does not have a strong preventive mandate, as a dispute settlement mechanism. The modest scope of this work is not intended to embark on an indepth analysis of the relevant procedural aspects relating to structural discrimination.
} 
on the population as a whole or whether certain clusters sustain disproportionate impacts. The third is to verify whether the specific needs of these clusters were taken into consideration while designing and implementing a policy, thus removing them from political invisibility, coupled with their meaningful participation in the formulation of the relevant monitoring.

A clear sign of accepting the need to monitor instances of racial discrimination as a preventive obligation by States was given in 2009, during the Durban Review Conference, which updated the $2001^{74}$ original instrument. Although the relevant document only obtained consensus with difficulty, the States did agree on the importance of strengthening efforts, through several ways, in monitoring instances of human racial discrimination. ${ }^{75}$

Council Directive 2000/43/EC (the EU Racial Directive) establishes, under Article 13, that each EU Member State should designate one or more bodies to be in charge of the promotion of racial equality, the elaboration of surveys on incidents of racial discrimination and publishing reports based on these surveys. ${ }^{76}$ Similarly, the Inter-American Convention on Racism mandates States parties to designate a domestic body to monitor the implementation of this treaty, which may have, to a certain extent, a monitoring role concerning instances of discrimination. At the UN level, within the framework of the Paris Principles, ${ }^{77}$ while member States are not obliged to establish a National Human Rights Institution, those States which decide to do so should provide their institution with a generic role in monitoring incidents of racial discrimination. ${ }^{78}$ The establishment and strengthening of monitoring bodies had also been embraced by the CERD. In qualitative terms, these bodies should be entrusted with a clear monitoring role ${ }^{79}$ and should be allocated with the necessary resources to properly discharge their functions. ${ }^{80}$ The ECRI has been active in, e.g., recommending the creation of systems to monitor racist incidents by the police in the context of racial profiling. ${ }^{81}$ The CERD, for its part, has inter alia underscored that algorithmic profiling systems should be continuously monitored as to

\footnotetext{
74 DDPA, para. 76.

75 Durban Review, paras. 40, 86, 114, and 132.

76 Council Directive 2000/43/EC of 29 June 2000 implementing the principle of equal treatment between persons irrespective of racial or ethnic origin, Official Journal L. 180, 19/07/2000 P. 0022-0026, Art. 13.2.

77 Principles relating to the Status of National Institutions (The Paris Principles), UN General Assembly Resolution 48/134 of 20 December 1993.

78 Idem, Art. 3(iv)(g).

79 See e.g., HRCttee, Concluding Observations on the Central African Republic, UN Doc. CCPR/C/ $\mathrm{CAF} / \mathrm{CO} / 3,2020$, para. 34.

${ }^{80}$ CMWCttee, Concluding Observations on Bosnia and Herzegovina. UN Doc. CMW/C/BIH/CO/3, 2019, para. 18(b).

81 ECRI, General Policy Recommendation No. 11, CRI (2007)39, para. 12. Similarly, CERD, General recommendation No. 36 (2020) on preventing and combating racial profiling by law enforcement officials, adopted on 17 December 2020, UN Doc. CERD/C/GC/36, para. 55. Regarding discrimination in employment, ECRI has also recommended the creation of specialized domestic bodies mandated to (a) implement, (b) monitor, (c) establish accountability mechanisms, (d) set indicators and benchmarks, (e) gather, and (f) monitor equality data, ECRI, General Policy Recommendation No. 14, CRI(2012)48, para. 10 .
} 
their discriminatory effects. ${ }^{82}$ Likewise, the CERD has reinforced that monitoring instances and tendencies of racial discrimination are key for compliance with the ICERD, i.a., in tackling racial hate speech. ${ }^{83}$

A failure to put in place a monitoring mechanism to prevent human rights violations, in general, has led to state liability through case law, ${ }^{84}$ but hardly ever in cases dealing with racial discrimination, including ones dealing with police brutality or third-party abuses. ${ }^{85}$ It is hoped that this systemic failure, exposed by the Black Lives Matter movement, and embraced by the relevant UN High Commissioner's report, will encourage future cases to determine a positive obligation to monitor instances of racial discrimination, thus enhancing the chances of a structural transformation instead of individual justice. This report recommends that:

Systemic racism needs a systemic response. States should adopt a systemic approach to combating racial discrimination through the adoption and monitoring of whole-of-government and whole-of-society responses that are contained in comprehensive and adequately resourced national and regional action plans ... ${ }^{86}$

This excerpt is sufficiently authoritative to convince both domestic and international judges of the need to provide justice with a broader reach through policies targeted towards racialized groups.

\subsubsection{Obligation to Prevent Racial Discrimination Directly by the Authorities-No Effective Prevention with Colour-Blind Policies}

A considerable body of case law has identified the precise circumstances in which the authorities are required to take concrete measures to prevent imminent acts of racial discrimination.

A very representative case requiring a proactive measure by the authorities is the Committee against Torture (CAT Cttee) case of Hajrizi Dzemajl et al. v. Yugoslavia (2002), in which the police had been called to protect a Roma community from violent attacks by villagers, including the torching of the Roma settlement's houses. Police officers arrived in the community and witnessed the attacks but took no action whatsoever to prevent these heinous attacks from materializing, even noting that there was indeed a turbulent climate. The Committee classified the authorities' behaviour as acquiescence in the context of CAT's Art. 16. The Committee also held that the effect of arson attacks against the Roma applicants' homes was so severe that it reached the level of degrading treatment. ${ }^{87}$ The police's attitude,

\footnotetext{
82 Idem, para. 60.

83 CERD, General recommendation No. 35-combating racist hate speech, adopted on 26 September 2013, UN Doc. CERD/C/GC/35, para. 47.

84 E.g., ECtHR, Öneryıldız v. Turkey [GC], No. 48939/99, para. 71 ECHR 2004-XII, para. 71.

85 See Sect. 3.2.

86 Police Brutality and Racism Report, para. 19.

87 CAT Committee, Hajrizi Dzemajl et al. v. Yugoslavia, Communication, No. 161/2000. Views of 2 December 2002, UN Doc. CAT/C/29/D/161/2000, para. 9.2.
} 
in this case, contrasts with the ECtHR's Király and Dömötör v. Hungary (2017), in which the police took several preventative measures to protect a Roma neighbourhood from attacks arising from a virulent extreme-right march, such as vehicle and identity checks, the implementation of a precautionary strategy, and constant monitoring. The police action was scrutinized by the country's Supreme Court according to the principle of proportionality. The ECtHR, recognizing the proactive behaviour of the State, exonerated it from any responsibility, even when the police had not dispersed the aggressive marchers, in light of the legislative framework in place that provided safeguards for the victims. ${ }^{88}$

The scope of the responsibility to prevent these imminent attacks, however, will considerably hinge on the quality of the knowledge obtained by the authorities in a concrete case. In a racial context, the knowledge parameter relates to the awareness by the security officers on the ground of any racial or ethnic sensitivity in a given police operation. For instance, when the police operate in areas that are densely populated by racialized groups, this specific knowledge may even be presumed, thus obliging the authorities to take additional measures of care to prevent any disproportional harm to these groups. This presumed risk of affecting marginalized communities was deemed to have been certainly the case in Wallace de Almeida v. Brazil, decided by the IACHR. ${ }^{89}$ The Commission noted the appalling rates of killings of young African descendants in slums in Brazil and held that any police intervention in those areas should be accompanied by positive action of care, ${ }^{90}$ in view of the 'distinctions based on de facto inequities for the protection of those who must be protected.' ${ }^{91}$ Thus, instead of entertaining elaborate reasoning on the racial motivation of the police (intent), the Commission simply applied an additional duty of care owing to the high probability of a black adolescent being killed in a slum area. Not only in the Americas but also worldwide, there is a pattern of police brutality and racism, as the UN High Commissioner for Human Rights has pointed out, revealing cases in which the mortality of racialized groups by security forces and police encounters with racialized groups are many times higher than among the remainder of society. ${ }^{92}$ The High Commissioner underscored:

In many of the incidents reviewed, the available information suggests that the victims did not pose an imminent threat of death or serious injury that would be necessary to justify the level of force used. Alleged use-of-force violations were most frequently associated with fatal gunshots, the disproportionate or

\footnotetext{
${ }_{88}$ ECtHR, Király and Dömötör v. Hungary, No. 10851/13, 17 January 2017, paras. 63-69.

89 IACHR, Wallace de Almeida v. Brazil, Case 12.440. Decision (Merits) of 20 March 2009. Report 26/09, para. 100. Compare with Vasil Sashov Petrov v. Bulgaria, No. 63106/00, para. 69, 10 June 2010, in which the ECtHR held that it was not possible for the authorities to know about the Roma ethnicity of the victim.

90 IACHR, Wallace de Almeida v. Brazil, paras. 145-146.

91 Idem.

92 Police Brutality and Racism Report, paras. 26 and 27.
} 
unnecessary use of restraining measures, the use of less-lethal weapons, or a combination thereof. ${ }^{93}$

Despite the welcome line of reasoning taken by the IACHR in the above case, it fell short of further elaborating that such specific knowledge, or racial awareness, can only be acquired through a number of means. Firstly, the police forces require intensive theoretical and practical training in racial discrimination with regard to police operations, stress conditions leading to racist acts, and the de-escalation of conflicts with a racial element. Secondly, the police forces themselves often require more than mere specific training, in view of the intrinsic biases that provide the grounds for the police tactics, thus necessitating changes in the whole security policies, which (mistakenly) see racially discriminated groups as sources of insecurity for the population at large. Such bias does not originate from the police forces alone but is a byproduct of the population at large, who, even if unconsciously, task the police with eliminating those who are labelled as enemies of society. The attitude of the police is only an extension of systemic racism that affects several other sectors of society, which is worsened by the rise of supremacist political platforms. The culture of accountability, when it exists, may be colour blind. Still, beyond official accountability, the police regulations on the lethal use of force in societies affected by serious problems of structural racism result in the social costs of killing marginalized groups being frequently very low, thereby incentivizing the police to perpetuate brutality against these groups. That is why the proportionate conviction of the police officer for the killing of George Floyd in April 2021 sends a positive signal worldwide that abuses of this type are not to be tolerated.

\subsubsection{Preventive Measures to Protect Indigenous Lands-Evolving Law on Qualified Participation}

During the last few decades the rights of indigenous peoples have gained growing attention from the international monitoring mechanisms, including a dedicated General Recommendation from the CERD, ${ }^{94}$ in which this Committee departed from the less integrationist approach of the original wording of the ICERD itself towards closer attention to specific ethnic identities. Moreover, the protection of indigenous peoples, which are marked by heightened vulnerability, has required international law, mainly the IACtHR, to widen its traditional individualist approach, for instance by accepting the concept of communal (instead of private) property and measures to protect it: e.g., an obligation to implement a policy of land demarcation for traditional lands, together with effective monitoring mechanisms. ${ }^{95}$ For this Court, it is not only important that States implement demarcation measures, but also that

\footnotetext{
93 Idem, para. 31.

94 CERD, General recommendation 23 on the rights of indigenous peoples (1997). UN Doc. A/52/18, 1997, Annex V, p. 122. The practice of racism against indigenous peoples is also recognized in the Durban Declaration, para. 39.

95 I IACtHR, Case of the Mayagna (Sumo) Awas Tingni Community v. Nicaragua. Merits, Reparations and Costs. Judgment of August 31, 2001. Series C No. 79, para. 138.
} 
they are effectively enforced ${ }^{96}$ by preventing any invasion by non-indigenous persons and corporations. ${ }^{97}$ In 2020, the IACHR granted interim measures in favour of the Yanomami people, in view of the invasion of their demarcated lands by illegal gold miners, who not only polluted the rivers within their land with mercury but also contributed to the spreading of COVID-19, thereby exposing these people to an extremely vulnerable situation. ${ }^{98}$

Another specific preventive measure to protect the rights of indigenous peoples is impact assessment studies, as mandated by Article 7.3 of ILO Convention No. 169. Similarly, in Saramaka v. Suriname (2007), the IACtHR recognized the existence of such an obligation under the ACHR, stating that socio-environmental impact assessments should ensure the rights of the communal use of land vis-à-vis industrial projects carried out on the lands of indigenous peoples. ${ }^{99}$

However, since the preventive obligations in this context are ethnic-specific, their effectiveness hinges substantively on the views and perspectives of the risks that the indigenous communities perceive in each concrete case. This is the underlying rationale of the State's duty to promote consultations with indigenous peoples. They consist of means in which the authorities obtain information ('knowledge') in this particular context, thus mitigating the risks of harm. Such an obligation is enshrined in Article 6 of ILO Convention 169, under which States must conduct meaningful consultations with communities affected by a project or a public policy. ${ }^{100} \mathrm{~A}$ more elaborate duty of this type is enshrined in the UN Declaration on the Rights of Indigenous Peoples ('UNDRIP') through the FPIC-the free, prior, and informed consent standard, ${ }^{101}$ which was embraced by the UN and Inter-American systems. ${ }^{102}$ A failure to initiate a consultation procedure is a human rights violation in itself. ${ }^{103}$ On other occasions, the obstruction of the consultation process by the State may be regarded as a breach of a preventive obligation of the State, as the IACHR decided in an interim decision in 2011. The Commission ordered the suspension of the

\footnotetext{
96 IACtHR, Case of the Sawhoyamaxa Indigenous Community v. Paraguay. Merits, Reparations and Costs. Judgment of March 29, 2006. Series C No. 146, para. 143.

97 IACHR, Indigenous and Tribal Peoples' Rights over Their Ancestral Land and Natural Resources, Norms and Jurisprudence of the Inter-American Human Rights System. OEA/Ser.L/V/II.Doc.56/09, 30 December 2009, para. 114.

98 IACHR, Medida Cautelar No. 563-20, Miembros de los Pueblos Indígenas Yanomami y Ye'kwana respecto de Brasil, 17 July 2020 (available only in Spanish and Portuguese).

99 IACtHR, Case of the Saramaka People. v. Suriname. Preliminary Objections, Merits, Reparations, and Costs. Judgment of November 28, 2007. Series C No. 172, para. 129.

100 ILO Convention 169, Art. 6.1(a), in conjunction with similar provisions in Arts. 15, 17, 22, 27 and 28.

101 UN Declaration on the Rights of Indigenous Peoples, UNGA Resolution 61/295. UN Doc. A/ RES/47/1 (2007), Art. 11.2.

102 IACtHR, Case of the Yakye Axa Indigenous Community v. Paraguay. Merits, Reparations and Costs. Judgment of June 17, 2005. Series C No. 125, para. 217. Similarly, ECtHR, Bagdonavicius and Others v. Russia, No. 19841/06, 11 October 2016, paras. 106-108, speaking of an obligation to consult Roma communities concerning policies that directly affect their rights.

103 See, e.g., the ILO's General Observation (CEACR) of 2008, published in the 98th ILC session (2009); and IACtHR Case of Kichwa Indigenous People of Sarayaku v. Ecuador. Merits and reparations. Judgment of June 27, 2012. Series C No. 245, para. 166.
} 
construction of a hydroelectric powerplant and dam near several indigenous communities in the absence of meaningful consultations. ${ }^{104}$

Such a role transcends the traditional scope of the due diligence standard. In addition to its preventive role, consultations aimed at obtaining the consent of indigenous peoples represent a platform for empowerment and participation by a social cluster with lower political and economic power. Indigenous peoples suffer an extreme imbalance of power vis-à-vis transnational corporations seeking economic gains in or near their lands. Thus, such a measure fills an important vulnerability gap and consists of an open door for strengthening the legal dialogue on structural discrimination.

\subsubsection{Delegation of Public Services to Private Companies and Racial Segregation-A Structural Dimension}

One of the issues dealt with by human rights law that fell short of considering the structural dimensions of racial discrimination is privatization, ${ }^{105}$ as well as other forms of the delegation of the State's essential functions. Privatizations were presented as a means of improving performance in servicing the population at large during the 1990s, although there has been a recent trend to return the conducting of essential services to public providers. ${ }^{106}$

On the contrary, in the last decade, arbitration panels have exonerated transnational corporations from direct international responsibility. ${ }^{107}$ Similarly, the Guiding Principles on Business and Human Rights have confined legal obligations concerning corporate violations to the domestic jurisdiction of States. ${ }^{108}$ Thus, a critical appraisal of the individual, collective and structural effects on racialized sectors when they attempt to access and use public services delegated to private entities is required.

The issue of delegating State functions to private actors, particularly essential public services, has been dealt with, until recently, in neutral terms, mainly by the recognition that States remain responsible for human rights violations caused by private actors performing these services. According to this neutral view, international human rights law did not forbid the performance of public services by private

\footnotetext{
104 IACHR, PM 382/10 - Indigenous Communities of the Xingu River Basin, Pará, Brazil.

105 The term 'privatization' in this article is used to designate the several forms by which the State delegates public functions to private entities, including the transfer of ownership from state-owned companies to the private sector, the transfer of management from state authorities to private entities, through the contracting out of services, and, more critically, the withdrawal of a certain function given the State's inability to manage it. See, Hallo de Wolf (2012), pp. 42-43.

106 See: a collection of studies on the renationalization of water services: Kishimoto et al. (2109).

107 E.g.: ICSID, Urbaser S.A. and Consorcio de Aguas Bilbao Bizkaia, Bilbao Biskaia Ur Partzuergoa v. The Argentine Republic, Case No. ARB/07/26.

108 Report of the Special Representative of the Secretary-General on the issue of human rights and transnational corporations and other business enterprises, John Ruggie: Guiding Principles on Business and Human Rights: Implementing the United Nations Protect, Respect and Remedy Framework. (The Guiding Principles on Business and Human Rights). UN Doc. A/HRC/17/31, Annex-General Principle, letter (a).
} 
companies but reminded States that they remain liable for violations perpetrated by non-state actors. ${ }^{109}$ This minimalist understanding was only criticized at a later state by authoritative legal writers ${ }^{110}$ and UN experts, ${ }^{111}$ who rejected any approach to the question of privatization and denounced the risks of the deprivation of essential services for impoverished groups.

The right to clean, safe water and sanitation provides us with an important platform for discussing systemic discrimination and privatization. It reveals the inextricable link between racism and poverty; it relates not only to the social dimension of access to water and sanitation but also to the political (in)ability of certain groups to influence the privatization processes (integrating rights). Moreover, this type of privatization, given its intrinsic operational nature, is often performed through natural monopoly schemes, which leaves impoverished racialized groups with no other market choice.

In 2013 the Special Rapporteur on the Human Right to Safe Drinking Water and Sanitation revealed another facet of the privatization of public services by stating: '[p]rofits made by the public sector are almost fully distributed among shareholders, rather than being reinvested in maintaining and extending service provision, the result being increased prices for consumers, continued need for public investment, and potentially unsustainable services. ${ }^{112}$

The Rapporteur kept on pointing to the lack of state control over these privatized services through measures that comprise the core of due diligence, such as regulation, monitoring, and long-term oversight. ${ }^{113}$ The relevant study was then a positive step, dealing with the risks facing marginalized groups, which were exemplified ${ }^{114}$ generically. At the same time, the study focused on remedial and compensatory provisions rather than on the empowerment and participation of these groups during the relevant privatization debates, which would have enhanced a more preventive approach. A more precise elaboration of the study would emphasize the inextricable relations between poverty, racism, and political powerlessness, leading to structural racial discrimination in the enjoyment of the right to water. ${ }^{115}$ Poverty and racism

\footnotetext{
109 De Feyter and Gómez Isa (2005), p. 3, representing a courageous work, but still elaborated in neutral terms. See, in the case law: ECtHR, O'Keeffe v. Ireland [GC], No. 35810/09, para. 150, ECHR 2014 (extracts); and in General Comments, e.g.: CESCR, General Comment No. 24 on State Obligations under the International Covenant on Economic, Social and Cultural Rights in the Context of Business Activities, adopted on 10 August 2017. UN Doc. E/C.12/GC/24, para. 22.

110 Nowak (2017), p. 108.

111 See e.g., UN Special Rapporteur on the Right Report of the Special Rapporteur on the Human Right to Safe Drinking Water and Sanitation, UN Doc. A/HRC/24/44, 2013.

112 Idem, para. 44.

113 Idem, para. 16.

114 Idem, para. 50.

115 Idem, paras. 48-49. See also the Police Brutality and Racism Report: 'With the racialization of poverty, disparate outcomes in terms of the enjoyment of economic and social rights are compounded by the insufficient meaningful participation and representation of people of African descent in decision-making processes and in public life. The level of representation in elected and other decision-making bodies in States where there are sizeable communities of people of African descent is substantially lower than the percentage of the population they represent', para. 13. Understandably, a study by a UN Rapporteur faces limitations as to its length and topics may lead the expert to make difficult choices in drafting it.
} 
go hand in hand. A new study presented to the UNGA in 2020, by a new Rapporteur, also on the privatization of water, only briefly addressed the principle of nondiscrimination, again without considering the structural dimensions of racism in relation to this right. ${ }^{116}$ However, in a visit report to India, this Rapporteur put forward important elements of due diligence in designing safeguards that may prevent instances of structural discrimination in the right to water and sanitation, ${ }^{117}$ integrating SDGs 6.1 (access to water) and 6.2 (sanitation and hygiene), and an obligation ex ante for the State to set up a normative framework and a monitoring system to prevent a structural deprivation of water and sanitation.

Despite these challenges, there is strictly no legal obstacle against human rights law pursuing a restrictive approach and not elaborating on structural discrimination. According to the current state of human rights law, racial segregation can occur without the intention of the authorities. ${ }^{118}$ The CERD has been particularly cognizant of non-intentional instances of racial segregation and has recommended, e.g., that licences granted to privately-owned bars and discotheques be accompanied by an express prohibition of racial discrimination. ${ }^{119}$

Moreover, in the context of positive obligations, there are different approaches to the term 'State' or 'public authority', instead of a fixed concept. ${ }^{120}$ In fact, a sharp demarcation between public actors and private actors, for the purpose of attributing international responsibility, has somewhat lost its importance, ${ }^{121}$ and, in the case of equality and non-discrimination, has often left violations unpunished. ${ }^{122}$ Moreover, the due diligence principle, as applied to human rights law, disregards the complexities of the general rules of State attribution, requiring mainly the knowledge of a violation (or its imminence) and the tolerance thereof by the authorities in order to give rise to State responsibility. In this context, the State's intent may serve as one among many criteria to ascertain the degree of this responsibility, rather than a decisive factor to establish responsibility, particularly when structural discrimination is at stake. The CERD, in General Recommendation No. 20, has somewhat recalibrated the intent factor, as it speaks only of the 'influence' of private actors in

\footnotetext{
116 Report of the Special Rapporteur on the Human Right to Safe Drinking Water and Sanitation, UN Doc. A/75/208, 2020.

117 UN Doc. A/HRC/39/55/Add.1, para. 54: 'While a large part of the population in India enjoys access to water and sanitation, certain groups in vulnerable situations are still being left behind, either due to lack of access to services or to the lower level of the services to which they have access [...] [t]o uphold the country's human rights obligations, it must develop methodologies that take into account the normative content of the human rights to water and sanitation, and monitor inequalities and non-discrimination in access to those services. The Special Rapporteur emphasizes the importance of adopting a national consensus on the next steps in water and sanitation policies so that no one is left behind.'.

118 E.g., CERD, The Prevention, Prohibition and Eradication of Racial Segregation and Apartheid, adopted at its forty-seventh session, UN Doc. A/50/18, 1995, p. 140, para. 4.

119 CERD, Concluding Observations on Norway. UN Doc. CERD/C/304/Add.88, para. 17.

120 See: Lavrysen (2016), pp. 243-246 and 254-260.

121 See, e.g., US Supreme Court, US Supreme Court, Burton v. Wilmington Parking Authority 365U.S. 71(1961). Compare with the ACHPR's Soc. and Econ. Rights Action Ctr. v. Nigeria, Communication. No. 155/96 (2001), where the Nigerian authorities provided an oil company with armed security that killed a number of members of an indigenous community.

122 See, e.g., Thornton (1991), pp. 448-463; Cusack and Pusey (2013), pp. 9-10.
} 
the exercise of rights and the availability of opportunities for racialized groups. ${ }^{123}$ In the same vein, the UN Guiding Principles on Business and Human Rights provide for an overarching principle of non-discrimination, which applies to the State obligation to monitor and regulate the private activity, without mentioning the intent requirement. $^{124}$

Further, the large imbalance of powers between large-scale service providers and racially vulnerable sectors that strongly rely on public services may cause or perpetuate racial exclusion in view of pre-existing structural inequalities. ${ }^{125}$

In this context, using the parameters adopted by the CESCR: economic accessibility (affordability), physical accessibility, and acceptability, helps to better grasp the contours of racial segregation in public services. Affordability is a key parameter in view of the natural impoverishment of marginalized sectors ${ }^{126}$ that rely greatly on progressive pricing policies. ${ }^{127}$ The application of different prices for the racialized poor may be required to ensure equal access to public services. This approach was confirmed by the South African Constitutional Court in City Council of Pretoria v. Walker (1997). ${ }^{128}$ Regarding physical accessibility, racial disadvantages have an important territorial component, ${ }^{129}$ risking, i.a., the closing or relocation of non-profitable facilities upon which disadvantaged communities greatly rely, ${ }^{130}$ such as health services located close to slum areas. Nomadic groups may be offered only precarious settlement spots devoid of public facilities and essential sanitation. ${ }^{131}$ Acceptability, in cultural terms, ${ }^{132}$ is key to ensuring, for instance, that new

\footnotetext{
123 CERD, General Recommendation No 20: Non-Discriminatory Implementation of Rights and Freedoms (Art. 5), 15 March 1996. UN Doc. A/51/18, Annex VIII A, para. 5.

124 UN Guiding Principles on Business and Human Rights, (General Principles) 3rd para. para. See also, Art. 18, commentary and Art. 20 (commentary, 2nd para.) speaking of particular instances of vulnerability and marginalization.

125 See, for instance, in the case of the privatization of water supply in South Africa after the Apartheid regime: Morris (2012), pp. 16-23.

126 Stein, apud Kok (2005), p. 265.

127 CESCR, General Comment No. 15: The Right to Water, adopted on 20 January 2003. UN Doc. E/C.12/2002/11, para. 27, explaining that poorer households should not be disproportionately burdened with water expenses as compared to richer households. See also the concluding observations on Nepal (right to water), E/C.12/1/ADD.66, para. 60; on Kazakhstan (social security), E/C.12/KAZ/CO/1; and on Venezuela (health care), E/C.12/1/Add.56, para. 29.

128 See: e.g., Constitutional Court of South Africa, City Council of Pretoria v. Walker, Case CCT 8/ 19974 SA 189. The Court held that differentiated electricity and water pricing policies and payment collections were constitutional, by which white communities were charged per cubic meter of water consumed, whereas the black counterparts were charged on a flat-rate basis, also in view of the poor condition of the infrastructure in the black neighbourhoods.

129 E.g., CESCR, General Comment No. 14: The Right to the Highest Attainable Standard of Health, 11 May 2000, UN Doc. E/C.12/2000/4, para. 12: ('health facilities, goods and services must be within safe physical reach for all sections of the population, especially vulnerable or marginalized groups, such as ethnic minorities and indigenous populations...'). On regional inequalities, see: CERD, Concluding Observations on Madagascar, UN Doc. CERD/C/65/CO/4, para. 16. See also Vandenhole (2005), p. 41.

130 Randall (2001), p. 6.

131 Fredman (2011), p. 70.

132 CESCR, General Comment No. 12: The Right to Adequate Food (Art. 11 of the Covenant), 12 May 1999, UN Doc. E/C.12/1999/5, para. 8: 'acceptable within a given culture'. See also the 'non nutrientbased values' in this context, para. 11.
} 
consumption habits do not harm traditional practices of indigenous peoples and thus negatively impact their rights, ${ }^{133}$ such as the right to health, in view of the exhaustion of traditional resources by extractive activities, forcing them to acquire such goods and products, affecting their right to health. ${ }^{134}$

Beyond a neutral approach that simply reaffirms the state obligation in the context of privatization, the risks of the exclusion of marginalized groups in accessing essential public services represent a more appropriate view of the contemporary human rights challenges facing the poor strata of society. Further, poverty frequently has colour, which requires better integration between racial discrimination and poverty in the current legal dialogues. Moreover, the poor and racialized are also political actors (and agents of change), not only groups in need of social rights. Therefore, the structural transformation will empower these disfranchised voices by enhancing their civil and political rights (freedom of expression, freedom of assembly, and equal participation) in every policy that affects their daily lives.

\section{Concluding Comments and Reflections}

The due diligence standard has had a fundamental role in making human rights effective, rather than merely a formality. Coupled with the principle of substantive (racial) equality, many individual victims of racial discrimination could finally obtain redress. The prevention of violations, including acts of racial discrimination, lies at its core. Yet, it is not a standard that is built to address specifically structural racial discrimination. Arguably, actions such as the enactment of legislation, monitoring and participation have a positive impact on the relevant root causes, but such impact remains limited to factors not pertaining to the very nature of this standard.

The concept of due diligence has been construed as a part of the so-called 'duty to protect', which in itself does not contain obligations such as temporary special measures and education for the purpose of equality. Hence, this standard, as it was designed, is not endowed with a complete toolbox for complete structural transformation, such as the obligations contained in the so-called 'duty to fulfil'. ${ }^{135}$ Arguably, this methodological concept of the tripartite 'typology of duties', of a silo nature, may hamper more integrated formulations, in the sense that racial discrimination, including its structural manifestations, requires a set of coordinated actions from States. However, relevant claims can be better framed, as in the example of

\footnotetext{
133 The right to food for indigenous peoples is closely related to the tenure and control of their traditionally occupied lands, see: Preliminary Study of the Human Rights Council Advisory Committee on Discrimination in the Context of the Right to Food, UN Doc. A/HRC/AC/6/CRP.1, 2010, para. 51. For instance, the Special Rapporteur on the Right of Indigenous Peoples has recommended that Kenya should revise the policy of the privatization of communal ranches, with the participation of the communities concerned, to counteract the negative consequences of the 'willing seller-willing buyer' practice. UN Doc. A/HRC/4/32/Add.3, para. 101.

134 See, e.g., Soares et al. (2015).

135 For a detailed view of the so-called 'tripartite typology of duties', see Lugon Arantes (2019), pp. 64-107 (in general) and 335-380 (in the context of racial discrimination).
} 
the need for specific training for police forces, in order to identify any racial implications during policing operations (thus generating precise knowledge of the particular violation). Racial awareness in police operations requires, in turn, disaggregated data and a monitoring mechanism to be in place, all parts of a comprehensive toolbox.

The concept of substantive racial equality, coupled with the due diligence standard, has great potential for enhancing the structural effects in concrete cases. However, to a considerable extent, the former has been confined within the traditional approach of individual rights and individual justice, as the relevant claims are often formulated in those terms. Yet, substantive equality can and should strengthen claims for structural measures, by making explicit the specificities of racial discrimination and exclusion in a concrete case, and by identifying the root causes of a multitude of violations. It would be a welcome step, for instance, to further combine racialization and poverty, which keeps large groups marginalized from access and opportunities in society.

Another factor compromising the potential of due diligence to deal with structural discrimination is still an obsolete concept of hierarchies of rights, by which CPRs, classic and justiciable rights, prevail over the unclear, programmatic and nonjusticiable ESCR. Such an understanding may lead one to conclude that racialized groups require social assistance, or the provision of goods, but not rights of political empowerment and a stronger voice in matters that affect their daily lives. In qualitative terms, this is a serious obstacle for human rights litigation to address structural discrimination since it deals only with one facet of the problem. In fact, these groups require both types of rights, which are universal, indivisible, interdependent and mutually reinforcing. The main general human rights treaties were adopted under this fragmented philosophy, which limits the scope of action of the relevant monitoring mechanism. Yet, these mechanisms can, as far as possible, deal with claims in a more integrated fashion.

Future research on the matter can make a significant contribution by studying the potential with which the current international human rights petition mechanisms can address structural discrimination. One can also argue that there is a need to envisage other new mechanisms dealing with violations that directly address this phenomenon, beyond an individualist perspective, which can also be the object of further research.

\section{References}

Abramovich V (2009) From massive violations to structural patterns: new approaches and classic tensions in the inter-American human rights system. Sur J Int Law 6(11):7-36

Alves L (2008) Race and religion in the United Nations Committee on the elimination of racial discrimination. Univ San Franc Law Rev 42:941-982

Brems E (2014) Should pluriform human rights become one? Exploring the benefits of human rights integration. Eur J Hum Rights 4:447-470

Cusack S, Pusey L (2013) CEDAW and the right to non-discrimination and equality. Melb J Int Law 14:1-39

De Beco G (2013) Human rights indicators: from theoretical debate to practical application. J Hum Rights Pract 5(2):380-397 
De Feyter K, Gómez Isa R (2005) Privatization and human rights - an overview. In: De Feyter K et al (eds) Privatisation and human rights in the age of globalisation. Intersentia, Antwerp

De Schutter O, Ringelheim J (2010) Ethnic monitoring: the processing of racial and ethnic data in anti-discrimination policies: reconciling the promotion of equality with privacy rights. Bruylant, Brussels

Fredman S (2011) Discrimination law, 2nd edn. Clarendon, Oxford

Fredman S, Spencer S (2006) Beyond discrimination: it's time for enforceable duties on public bodies to promote equality outcomes. Eur Hum Rights Law Rev 6:598-606

Gaeta P (2007) On what conditions can a state be held responsible for genocide? Eur J Int Law 18(4):631-648

Hallo de Wolf A (2012) Reconciling privatization with human rights. Intersentia, Antwerp

Kishimoto S et al (2019) The future is public_-towards democratic ownership of public services. Transnational Institute, Amsterdam

Kok A (2005) Reforming the Water and Sanitation Sector in South Africa” Pretoria. In: De Feyter K et al (eds) Privatisation and human rights in the age of globalisation. Intersentia, Antwerp

Lavrysen L (2016) Human rights in a positive state-rethinking the relationship between positive and negative obligations under the European convention on human rights. Intersentia, Antwerp

Lerner N (2014) The UN convention on the elimination of all forms of racial discrimination-(reprint revisited). Brill/Nijhoff, Dordrecht

Lugon Arantes P (2019) The content and extent of positive obligations in the protection against discrimination, with special attention for racial discrimination. PhD Thesis, Leuven. https://limo.libis.be/ primo-explore/fulldisplay?docid=LIRIAS2348596\&context=L\&vid=Lirias\&search_scope=Liria s\&tab=default_tab\&lang=en_US\&fromSitemap=1. Accessed 6 December 2021

Mahalic D, Mahalic J (1987) The limitation provision of the international convention on the elimination of all forms of racial discrimination. Hum Rights Q 9(1):74-101

Makkonen T (2012) Equal in law, unequal in fact-racial and ethnic discrimination and the legal response thereto in Europe. Martinus Nijhoff Publishers, Leiden

Meron T (1985) The meaning and reach of the international convention on the elimination of all forms of racial discrimination. Am J Int Law 79(2):283-318

Morris B (2012) Water apartheid? A case study examining the parallels between water privatization in neoliberal South Africa and inequalities in Apartheid. Trial Six 6(16):23

Nowak M (2017) Human rights or global capitalism - the limits of privatization. University of Pennsylvania Press, Philadelphia, PA

Peroni M, Timmer A (2013) Vulnerable groups: the promise of an emerging concept in European human rights convention law. ICON-Int J Constitut Law 11(4):1056-1085

Randall V (2001) Race, health care and the law, regulating racial discrimination in health care. https:// unrisd.org/80256B3C005BCCF9/(httpAuxPages)/603AC6BDD4C6AF8F80256B6D005788BD/ \$file/drandall.pdf. Accessed 6 December 2021

Schwelb E (1996) The international convention on the elimination of all forms of racial discrimination. Int Comp Law Q 1504:996-997

Simon P (2012) Collecting ethnic statistics in Europe: a review. Ethn Racial Stud 35(8):1366-1391

Soares L et al (2015) Prevalence of metabolic syndrome in the Brazilian Xavante indigenous population. Diabetol Metab Syndr. https://doi.org/10.1186/s13098-015-0100-X

Spielmann D (1995) L'effet potentiel de la Convention Européenne des Droits de l'Homme entre Personnes Privées. Bruylant, Brussels

Thornton M (1991) The public/private dichotomy: gendered and discriminatory. J Law Soc 18(4):448-463

Vandenhole W (2005) Non-discrimination and equality in the view of the UN treaty bodies. Intersentia, Antwerp

Publisher's Note Springer Nature remains neutral with regard to jurisdictional claims in published maps and institutional affiliations. 